\title{
Relationship between structural properties and affinity for herpes simplex virus type 1 thymidine kinase of bromine substituted 5-heteroaromatic 2'- deoxyuridines
}

\author{
Isabelle Creuven ${ }^{\mathrm{a}}$, Christine Evrard ${ }^{\mathrm{a}}$, Anne Olivier ${ }^{\mathrm{a}}$, Guy Evrard $^{\mathrm{a}}$, Arthur Van Aerschot ${ }^{\mathrm{b}}$, Piet Wigerinck ${ }^{\mathrm{b}}$, Piet \\ Herdewijn ${ }^{\mathrm{b}}$, Francois Durant ${ }^{3}$ \\ ${ }^{a}$ Laboratoire de Chimie Moléculaire Structurale, Facultés Universitaires Notre-Dame de la Paix, rue de Bruxelles 61, B-5000 Namur, \\ Belgium ${ }^{b}$ Laboratory of Medicinal Chemistry, Rega Institute for Medical Research, Katholieke Universiteit Leuven, B-3000 Leuven, Belgium
}

\begin{abstract}
The crystal structures of 5-(5-furan-2-yl)-2'-deoxyuridine (II), 5-(5-bromofuran-2-yl)-2'-deoxyuridine (IV) and 5-(3-bromothien-2-yl)-2'-deoxyuridine (V) have been studied in order to explain the different affinity of the compounds for the herpes simplex virus type 1 (HSV-1) thymidine kinase. These compounds present a variable affinity according to the position of the heteroatom substituting the five-membered ring. An unfavourable substitution in the five-membered ring for interaction with the HSV-1 thymidine kinase has been identified.
\end{abstract}

Keywords: X-ray diffraction; Antiviral activity; Nucleoside; Herpes simplex virus type 1 (HSV-1); 5-substituted 2'-deoxyuridine; Thymidine kinase

\section{Introduction}

Attempts to identify antiherpes agents by a rational drug design approach have not been very successful till now. A number of nucleoside analogues are known to inhibit herpes simplex virus (HSV) replication (De Clercq and Torrence, 1978; De Clercq, 1981) but they were discovered by accident. This is partially due to the fact that a systematic study of the structure of the targets for the antiviral nucleosides has not been carried out. Also the study of the structural requirements of the modified nucleosides for antiherpes activity has not been done profoundly. In continuation of our research on the structure/anti-HSV-1 activity relationships of modified nucleosides, we studied the structural properties of a new series of 5-heteroaromatic substituted 2'-deoxyuridines.

The mechanism of action of these modified nucleosides (Derse et al., 1981; De Clercq et al., 1986) involves virus-encoded enzymes important in DNA replication, among them thymidine kinase (TK) and DNA polymerase. TK catalyses the transfer of the $\gamma$-phosphoryl group of ATP to the 5'-OH of thymidine to provide dTMP, an important precursor of HSV-1 DNA synthesis. The DNA polymerase catalyses replication of the viral genome. The HSV-1 thymidine kinase is particularly tolerant for pyrimidine 2'-deoxynucleosides substituted at the 5-position of the base, and many such compounds display antiherpes activity. Their selectivity primarily depends upon a preferential activation (phosphorylation) by the HSV-1 encoded TK (Desgranges et al., 1983). Next they are converted to their 5'-triphosphate form, interact with virus-specific DNA polymerase and disrupt viral replication by inhibiting the polymerase and/or by incorporation into viral DNA (Elion et al., 1977; De Clercq et al., 1979; Ruth and Cheng, 1981). The great potential of this class of compounds is demonstrated by the clinical use of 5-(2-bromovinyl)-2'-de-oxyuridine (BVDU) which in vitro and in vivo inhibits the replication of HSV-1 and varicella zoster virus (VZV). This compound, however, has the disadvantage that it is rapidly cleaved by phosphorylases, resulting in formation of the antivirally inactive bromovinyluracil. Phosphorylase stable 5-substituted 2'-deoxynu-cleosides might thus have some advantage over BVDU.

In an effort to try to improve the properties of existing 5-substituted pyrimidine nucleoside analogues we have synthesized several 5-heteroaromatic substituted congeners (Wigerinck et al., 1991a; Wigerinck et al., 1991b; Wigerinck et al., 1993). Many among them demonstrate potent anti-HSV-1 activity. These active compounds are selectively phosphorylated by the viral TK (Bohman et al., 1994).

Here we report on the structure-TK affinity relationships of 5-(5-furan-2-yl)-2'-deoxyuridine, 5-(5-bromofuran2-yl)-2'-deoxyuridine and 5-(3-bromothien-2-yl)-2'-deoxyuridine and compare them with the structural properties of 5-(5-thien-2-yl)-2'-deoxyuridine and 5-(5-bromothien-2-yl)-2'-deoxyuridine (Creuven et al., 1995). 
Fig. 1. I: 5-(5-thien-2-yl)-2'-deoxyuridine. II: 5-(5-furan-2-yl)-2'-deoxyuridine. III: 5-(5-bromothien-2-yl)-2'deoxyuridine. IV: 5-(5-bromofuran-2-yl)-2'-deoxyuridine. V: 5-(3-bromothien-2-yl)-2'-deoxyuridine.<smiles>O=c1[nH]c(=O)n(C2CC(O)C(CO)O2)cc1-c1cccs1</smiles>

I : 5-(5-thien-2-yl)-2'-dUrd $\mathrm{IC}_{50}=2.4 \mu \mathrm{M}$<smiles>O=c1[nH]c(=O)n(C2CC(O)C(CO)O2)cc1-c1ccco1</smiles>

II : 5-(5-furan-2-yl)-2'-dUrd $\mathrm{IC}_{50}=2.9 \mu \mathrm{M}$<smiles>O=c1[nH]c(=O)n(C2CC(O)C(CO)O2)cc1-c1ccc(Br)s1</smiles>

III : 5-(5-bromothien-2-yl)-2'-dUrd $\mathrm{IC}_{50}=3.5 \mu \mathrm{M}$<smiles>O=c1[nH]c(=O)n(C2CC(O)C(CO)O2)cc1-c1ccc(Br)o1</smiles>

IV : 5-(5-bromofuran-2-yl)-2'-dUrd $\mathrm{IC}_{50}=51 \mu \mathrm{M}$<smiles>O=c1[nH]c(=O)n(C2CC(O)C(CO)O2)cc1-c1sccc1Br</smiles>

V : 5-(3-bromothien-2-yl)-2'-dUrd $\mathrm{IC}_{50}=61.4 \mu \mathrm{M}$ 
Table 1: Crystal data for compounds II, IV and V

\begin{tabular}{|c|c|c|c|}
\hline & II & IV & $\mathrm{V}$ \\
\hline Compound & $\mathrm{C}_{\mathrm{I} 3} \mathrm{H}_{14} \mathrm{~N}_{2} \mathrm{O}_{6}$ & $\left(\mathrm{C}_{13} \mathrm{H}_{13} \mathrm{~N}_{2} \mathrm{O}_{6} \mathrm{Br} . \mathrm{H}_{2} \mathrm{O}\right)_{2}$ & $\mathrm{C}_{13} \mathrm{H}_{13} \mathrm{~N}_{2} \mathrm{O}_{5} \mathrm{SBr}$ \\
\hline Formula weight & 294.3 & 782.4 & 389.2 \\
\hline Crystal system & Monoclinic & monoclinic & Hexagonal \\
\hline Space group & $\mathrm{P} 2_{1}$ & $\mathrm{C}_{2}$ & $\mathrm{P} 6_{1}$ \\
\hline \multicolumn{4}{|l|}{ Cell constants } \\
\hline$a(\AA)$ & $10.352(3)$ & $21.289(3)$ & $20.421(3)$ \\
\hline$b(\AA)$ & $20.723(3)$ & $6.7850(9)$ & $20.421(3)$ \\
\hline$c(\AA)$ & $6.016(2)$ & $22.592(3)$ & $6.487(4)$ \\
\hline$\beta\left(^{\circ}\right)$ & $91.131(13)$ & $113.331(12)$ & $90.0(1)$ \\
\hline$\gamma\left({ }^{\circ}\right)$ & $90.0(1)$ & $90.0(1)$ & $120.0(1)$ \\
\hline Cell volume $\left(\AA^{3}\right)$ & $1290.23(8)$ & $2996.5(8)$ & $2342.8(36)$ \\
\hline Unit cell & 4 & 2 & 6 \\
\hline$\beta_{\text {calc }}\left(\mathrm{g} / \mathrm{cm}^{3}\right)$ & 1.515 & 1.734 & 1.587 \\
\hline$\mu_{\text {calc }}\left(\mathrm{cm}^{-1}\right)$ & 1.1 & 41.3 & 50.7 \\
\hline Crystal dimensions (mm) & $0.25 \times 0.19 \times 0.17$ & $0.36 \times 0.11 \times 0.07$ & $0.3 \times 0.1 \times 0.13$ \\
\hline Reflections measured & 3971 & 3296 & 7592 \\
\hline Reflections observed $\left[F_{0} \geq 4 \sigma\left(F_{0}\right)\right]$ & 3188 & 3212 & 2086 \\
\hline$R_{\text {int }}$ & 0.008 & 0.022 & 0.074 \\
\hline GOF & 1.10 & 1.02 & 1.09 \\
\hline $\mathrm{R}=\sum|| F_{0}|-| F_{c}|/ \Sigma|\left|F_{0}\right|$ & 0.048 & 0.034 & 0.062 \\
\hline $\mathrm{WR}^{2}$ & 0.106 & 0.095 & 0.169 \\
\hline$(\Delta / \sigma)_{\max }$ & 0.376 & 0.26 & 0.006 \\
\hline$(\Delta p)_{\min }\left(\mathrm{e} \AA^{3}\right)$ & -0.21 & -0.72 & -0.39 \\
\hline$(\Delta p)_{\max }\left(\mathrm{e} \AA^{3}\right)$ & 0.37 & 0.41 & 1.13 \\
\hline
\end{tabular}


Table 2 Final atomic coordinates of non-hydrogen atoms and thermal parameters $\left(\times 10^{4}\right)$ with E.S.D. values in parentheses for 5-(5-furan-2-yl)-2'-deoxyuridine (II)

\begin{tabular}{|l|l|l|l|l|}
\hline Atoms & $x / a$ & $y / b$ & $z / c$ & $\mathrm{U}^{\mathrm{a}} \mathrm{q}$ \\
\hline $\mathrm{O}(06)$ & $5401(3)$ & $148(2)$ & $-1582(5)$ & $38(1)$ \\
\hline $\mathrm{C}(01)$ & $4762(5)$ & $-154(3)$ & $-3281(7)$ & $46(1)$ \\
\hline $\mathrm{C}(02)$ & $3487(5)$ & $-60(3)$ & $-3116(7)$ & $45(1)$ \\
\hline $\mathrm{C}(03)$ & $3314(4)$ & $324(3)$ & $-1240(7)$ & $40(1)$ \\
\hline $\mathrm{C}(04)$ & $4485(4)$ & $431(3)$ & $-295(7)$ & $28(1)$ \\
\hline $\mathrm{C}(05)$ & $4984(4)$ & $767(2)$ & $1648(7)$ & $27(1)$ \\
\hline $\mathrm{C}(06)$ & $4086(4)$ & $1084(3)$ & $3161(6)$ & $28(1)$ \\
\hline $\mathrm{O}(01)$ & $2917(3)$ & $1106(2)$ & $2941(5)$ & $43(1)$ \\
\hline $\mathrm{N}(01)$ & $4688(3)$ & 1377 & $4951(5)$ & $29(1)$ \\
\hline $\mathrm{C}(07)$ & $5978(4)$ & $1406(3)$ & $5476(7)$ & $29(1)$ \\
\hline $\mathrm{O}(02)$ & $6410(3)$ & $1689(2)$ & $7134(4)$ & $32(1)$ \\
\hline $\mathrm{N}(02)$ & $6761(3)$ & $1106(2)$ & $3956(5)$ & $27(1)$ \\
\hline $\mathrm{C}(08)$ & $6252(4)$ & $796(3)$ & $2118(7)$ & $31(1)$ \\
\hline $\mathrm{O}(03)$ & $8787(3)$ & $974(2)$ & $2378(5)$ & $35(1)$ \\
\hline $\mathrm{C}(09)$ & $8183(4)$ & $1172(3)$ & $4334(7)$ & $30(1)$ \\
\hline $\mathrm{C}(10)$ & $8715(4)$ & $744(3)$ & $6192(7)$ & $42(1)$ \\
\hline $\mathrm{C}(11)$ & $10086(4)$ & $644(3)$ & $5438(8)$ & $41(1)$ \\
\hline $\mathrm{O}(04)$ & $10785(3)$ & $1195(3)$ & $6114(6)$ & $65(1)$ \\
\hline $\mathrm{C}(12)$ & $9941(4)$ & $606(3)$ & $2902(8)$ & $40(1)$ \\
\hline $\mathrm{C}(13)$ & $9847(7)$ & $-64(4)$ & $1867(12)$ & $76(2)$ \\
\hline $\mathrm{O}(05)$ & $8944(5)$ & $-410(3)$ & $2877(11)$ & $101(3)$ \\
\hline $\mathrm{O}(26)$ & $3433(3)$ & $3682(2)$ & $6303(5)$ & $42(1)$ \\
\hline $\mathrm{C}(21)$ & $3989(5)$ & $3981(3)$ & $8143(7)$ & $47(1)$ \\
\hline $\mathrm{C}(22)$ & $5249(5)$ & $3832(3)$ & $8329(8)$ & $43(1)$ \\
\hline $\mathrm{C}(23)$ & $5529(4)$ & $3423(3)$ & $6511(8)$ & $38(1)$ \\
\hline $\mathrm{C}(24)$ & $4420(4)$ & $3327(3)$ & $5314(7)$ & $31(1)$ \\
\hline $\mathrm{C}(25)$ & $4065(4)$ & $2997(3)$ & $3298(7)$ & $31(1)$ \\
\hline $\mathrm{C}(26)$ & $5039(4)$ & $2659(3)$ & $2116(7)$ & $32(1)$ \\
\hline $\mathrm{O}(21)$ & $6185(3)$ & $2611(2)$ & $2635(5)$ & $42(1)$ \\
\hline $\mathrm{N}(21)$ & $4595(3)$ & $2343(2)$ & $195(6)$ & $30(1)$ \\
\hline $\mathrm{C}(27)$ & $3378(4)$ & $2361(3)$ & $-673(7)$ & $29(1)$ \\
\hline $\mathrm{O}(22)$ & $3059(3)$ & $2075(2)$ & $-2404(5)$ & $40(1)$ \\
\hline $\mathrm{N}(22)$ & $2497(3)$ & $2720(2)$ & $469(6)$ & $29(1)$ \\
\hline $\mathrm{C}(28)$ & $2848(4)$ & $3012(3)$ & $2451(7)$ & $28(1)$ \\
\hline $\mathrm{O}(23)$ & $682(3)$ & $3386(2)$ & $75(5)$ & $32(1)$ \\
\hline $\mathrm{C}(29)$ & $1166(4)$ & $2772(3)$ & $-505(7)$ & $29(1)$ \\
\hline $\mathrm{C}(30)$ & $237(4)$ & $2269(3)$ & $360(8)$ & $38(1)$ \\
\hline $\mathrm{C}(31)$ & $-1040(4)$ & $2622(3)$ & $174(8)$ & $39(1)$ \\
\hline $\mathrm{O}(24)$ & $-1563(3)$ & $2600(2)$ & $-2036(5)$ & $51(1)$ \\
\hline $\mathrm{C}(32)$ & $-681(4)$ & $3326(3)$ & $658(8)$ & $39(1)$ \\
\hline $\mathrm{C}(33)$ & $-833(5)$ & $3547(3)$ & $2993(9)$ & $56(2)$ \\
\hline $\mathrm{O}(25)$ & $-172(4)$ & $3157(3)$ & $4562(6)$ & $85(2)$ \\
\hline
\end{tabular}

${ }^{\mathrm{a}}\left(\mathrm{U}_{\mathrm{eq}}=1 / 3 \mathrm{~S}_{\mathrm{i}} \mathrm{S}_{\mathrm{j}} \mathrm{u}_{\mathrm{ij}} \mathrm{a}{ }_{\mathrm{i}} a{ }^{*}{ }_{\mathrm{j}} a_{\mathrm{i}} a_{\mathrm{j}}\right)$ 


\section{Material and methods}

\subsection{Compounds}

The compounds used in this study are depicted in Fig. 1. The synthesis of 5-(5-thien-2- yl)-2'-dUrd (I), 5-(5furan-2-yl)-2'-dUrd (II), 5-(5-bromothien-2-yl)-2'-dUrd (III), 5-(5-bromo-furan-2-yl)-2'-dUrd (IV) (Wigerinck et al., 1991a) and 5-(3-bromothien-2-yl)-2'-dUrd (V) (Luyten et al., 1995) has been described before. Also their $\mathrm{IC}_{50}$ for the HSV-1 thymidine kinase is given in Fig. 1. These data were previously published (Bohman et al., 1994; Luyten et al., 1995). The crystal structure of compounds I and III have been published elsewhere (Creuven et al., 1995).

\subsection{X-ray diffraction}

Prismatic colourless crystals were obtained at room temperature by slow evaporation of a methanol solution (compound II), of an ethanol solution with a few water drops (compound IV) and of a methanol/acetonitrile mixture (compound V).

Crystal data for compounds II, IV and V are reported in Table 1. The X-ray intensities were collected on a graphite-monochromated CAD-4 Enraf-Nonius diffractometer with $\mathrm{MoK} \alpha$ radiation $(1=0.71073)$ using $\omega-\theta$ scan for compounds II, and with $\mathrm{Cu} K \alpha$ radiation $(\Lambda=1.54178)$ using $\omega$ - $2 \theta$ scan for compounds IV and V.

Lorentz and polarization corrections were applied for the three data sets, while psi-scan absorption correction was applied only for IV $\left(T_{\min }=0.300\right.$ and $\left.T_{\max }=0.454\right)$.

The structures were solved by the application of direct methods (SHELXS86 program) (Sheldrick, 1986) and refined by full-matrix least squares on $F^{2}$ (SHELXL93) (Sheldrick, 1993). A number of 2989, 3103 and 2220 reflections were used during subsequent structure refinement for compounds II, IV and V, respectively. Nonhydrogen atoms were refined anisotropically while $\mathrm{H}$ atoms were included but not refined.

Structure refinement of II, IV and V converged to values of $R=0.048, R=0.034$ and $R=0.062$, respectively. Note that the intensity data of compound $V$ were collected on the basis of a monoclinic crystal system and were treated like a hexagonal system to solve the structure. The final geometrical analysis was performed by the PLATON92 program (Spek, 1990) and the representation of crystal packing by the ORTEP program (Johnson, 1976). 
Table 3 Final atomic coordinates of non-hydrogen atoms and thermal parameters $\left(\times 10^{4}\right)$ with E.S.D. values in parentheses for 5-(5-bromo-furan-2-yl)-2'-deoxyuridine (IV); W stands for the oxygen atom of a water molecule

\begin{tabular}{|c|c|c|c|c|}
\hline Atoms & $x / a$ & $y / b$ & $z / c$ & $U_{e q}^{\mathrm{a}}$ \\
\hline $\operatorname{Br}(01)$ & $-4626(1)$ & 9837 & $-663(1)$ & $49(1)$ \\
\hline $\mathrm{C}(01)$ & $-3706(2)$ & $9983(8)$ & $-127(2)$ & $35(1)$ \\
\hline $\mathrm{C}(02)$ & $-3370(2)$ & $10073(8)$ & $523(2)$ & $40(1)$ \\
\hline $\mathrm{C}(03)$ & $-2664(2)$ & $10120(8)$ & $633(2)$ & $38(1)$ \\
\hline $\mathrm{C}(04)$ & $-2615(2)$ & $10069(7)$ & $56(2)$ & $30(1)$ \\
\hline $\mathrm{O}(06)$ & $-3263(1)$ & $9992(6)$ & $-425(1)$ & $34(1)$ \\
\hline $\mathrm{C}(05)$ & $-2067(2)$ & $10072(7)$ & $-166(2)$ & $27(1)$ \\
\hline $\mathrm{C}(06)$ & $-1355(2)$ & $9960(8)$ & $291(2)$ & $32(1)$ \\
\hline $\mathrm{O}(01)$ & $-1171(1)$ & $9948(7)$ & $881(1)$ & $47(1)$ \\
\hline $\mathrm{N}(01)$ & $-884(2)$ & $9908(7)$ & $23(1)$ & $34(1)$ \\
\hline $\mathrm{C}(07)$ & $-996(2)$ & $9938(8)$ & $-618(2)$ & $310)$ \\
\hline $\mathrm{O}(02)$ & $-536(1)$ & $9836(8)$ & $-810(1)$ & $45(1)$ \\
\hline $\mathrm{N}(02)$ & $-1678(2)$ & $10065(6)$ & $-1031(1)$ & $31(1)$ \\
\hline $\mathrm{C}(08)$ & $-2185(2)$ & $10148(7)$ & $-802(2)$ & $30(1)$ \\
\hline $\mathrm{O}(03)$ & $-2180(1)$ & $12052(6)$ & $-1942(1)$ & $37(1)$ \\
\hline $\mathrm{C}(09)$ & -1854(2) & $10197(7)$ & $-1723(2)$ & $33(1)$ \\
\hline $\mathrm{C}(10)$ & $-2351(2)$ & $8648(8)$ & $-2131(2)$ & $39(1)$ \\
\hline $\mathrm{C}(11)$ & $-2696(2)$ & $9689(9)$ & $-2765(2)$ & $42(1)$ \\
\hline $\mathrm{O}(04)$ & $-2272(2)$ & $9488(8)$ & $-3115(1)$ & $57(1)$ \\
\hline $\mathrm{C}(12)$ & $-2728(2)$ & $11832(8)$ & $-2574(2)$ & $39(1)$ \\
\hline $\mathrm{C}(13)$ & $-3394(3)$ & $12468(11)$ & $-2548(2)$ & $58(2)$ \\
\hline $\mathrm{O}(05)$ & $-3571(2)$ & $11138(9)$ & $-2148(2)$ & $70(1)$ \\
\hline $\operatorname{Br}(21)$ & $-4052(1)$ & $7111(1)$ & $-4298(1)$ & $60(1)$ \\
\hline $\mathrm{C}(21)$ & $-3613(2)$ & $7173(9)$ & $-4860(2)$ & $42(1)$ \\
\hline $\mathrm{C}(22)$ & $-3829(2)$ & $7277(9)$ & $-5505(2)$ & $48(1)$ \\
\hline $\mathrm{C}(23)$ & $-3231(2)$ & $7309(9)$ & $-5638(2)$ & $41(1)$ \\
\hline $\mathrm{C}(24)$ & $-2687(2)$ & $7240(7)$ & $-5063(2)$ & $33(1)$ \\
\hline $\mathrm{O}(26)$ & $-2913(1)$ & $7156(6)$ & $-4570(1)$ & $40(1)$ \\
\hline $\mathrm{C}(25)$ & $-1950(2)$ & $7266(7)$ & $-4847(2)$ & $31(1)$ \\
\hline $\mathrm{C}(26)$ & $-1637(2)$ & $7194(8)$ & $-5311(2)$ & $34(1)$ \\
\hline $\mathrm{O}(21)$ & $-1942(2)$ & $7049(7)$ & $-5899(1)$ & $51(1)$ \\
\hline $\mathrm{N}(21)$ & $-929(2)$ & $7231(7)$ & $-5044(1)$ & $36(1)$ \\
\hline $\mathrm{C}(27)$ & $-506(2)$ & $7282(8)$ & $-4405(2)$ & $35(1)$ \\
\hline $\mathrm{O}(22)$ & $118(1)$ & $7241(8)$ & $-4216(1)$ & $49(1)$ \\
\hline $\mathrm{N}(22)$ & $-836(2)$ & $7398(6)$ & $-3989(1)$ & $32(1)$ \\
\hline $\mathrm{C}(28)$ & $-1543(2)$ & $7354(7)$ & $-4214(2)$ & $34(1)$ \\
\hline $\mathrm{O}(23)$ & $-483(2)$ & $5398(5)$ & $-3082(1)$ & $42(1)$ \\
\hline $\mathrm{C}(29)$ & $-421(2)$ & $7336(8)$ & $-3295(2)$ & $33(1)$ \\
\hline $\mathrm{C}(30)$ & $-614(2)$ & $8730(7)$ & $-2873(2)$ & $37(1)$ \\
\hline $\mathrm{C}(31)$ & $-322(2)$ & $7616(8)$ & $-2233(2)$ & $34(1)$ \\
\hline $\mathrm{O}(24)$ & $400(2)$ & $7905(8)$ & $-1945(1)$ & $57(1)$ \\
\hline $\mathrm{C}(32)$ & $-476(2)$ & $5504(8)$ & $-2439(2)$ & $37(1)$ \\
\hline $\mathrm{C}(33)$ & $-1169(2)$ & $4772(10)$ & $-2482(2)$ & $45(1)$ \\
\hline $\mathrm{O}(25)$ & $-1156(2)$ & $4745(7)$ & $-1846(2)$ & $54(1)$ \\
\hline $\mathrm{W}(01)$ & $-4596(4)$ & $7259(15)$ & $-3211(4)$ & $156(3)$ \\
\hline $\mathrm{W}(02)$ & $-3868(6)$ & 7194 (17) & $-1966(5)$ & $199(5)$ \\
\hline
\end{tabular}

${ }^{\mathrm{a}}\left(\mathrm{U}_{\mathrm{eq}}=1 / 3 \mathrm{~S}_{\mathrm{i}} \mathrm{S}_{\mathrm{j}} \mathrm{u}_{\mathrm{ij}} \mathrm{a}{ }_{\mathrm{i}} a *_{\mathrm{j}} a_{\mathrm{i}} a_{\mathrm{j}}\right)$ 
Table 4 Final atomic coordinates of non-hydrogen atoms and thermal parameters $\left(\times 10^{4}\right)$ with E.S.D. values in parentheses for 5-(4-bromo-thien-2-yl)-2'-deoxyuridine (V)

\begin{tabular}{|l|l|l|l|l|}
\hline Atoms & $\boldsymbol{x} / \boldsymbol{a}$ & $\boldsymbol{y} / \boldsymbol{b}$ & $z / \boldsymbol{c}$ & $U_{\text {eq }}$ \\
\hline $\mathrm{Br}(01)$ & $1452(1)$ & 8485 & $7(2)$ & $76(1)$ \\
\hline $\mathrm{S}(01)$ & $2916(1)$ & $10102(1)$ & $-4657(3)$ & $65(1)$ \\
\hline $\mathrm{C}(01)$ & $1994(7)$ & $9618(6)$ & $-5401(16)$ & $74(3)$ \\
\hline $\mathrm{C}(02)$ & $1544(6)$ & $9117(5)$ & $-4019(17)$ & $77(3)$ \\
\hline $\mathrm{C}(03)$ & $1955(5)$ & $9101(4)$ & $-2255(14)$ & $56(2)$ \\
\hline $\mathrm{C}(04)$ & $2714(4)$ & $9610(4)$ & $-2304(11)$ & $43(2)$ \\
\hline $\mathrm{C}(05)$ & $3306(4)$ & $9761(4)$ & $-853(11)$ & $40(2)$ \\
\hline $\mathrm{C}(06)$ & $3928(4)$ & $10528(4)$ & $-587(11)$ & $44(2)$ \\
\hline $\mathrm{O}(01)$ & $4041(4)$ & $11060(3)$ & $-1721(11)$ & $66(2)$ \\
\hline $\mathrm{N}(01)$ & $4410(4)$ & $10634(3)$ & $1028(10)$ & $45(1)$ \\
\hline $\mathrm{C}(07)$ & $4431(4)$ & $10092(4)$ & $2204(11)$ & $42(2)$ \\
\hline $\mathrm{O}(02)$ & $4889(3)$ & $10231(3)$ & $3568(9)$ & $56(1)$ \\
\hline $\mathrm{N}(02)$ & $3859(3)$ & $9356(3)$ & $1773(10)$ & $39(1)$ \\
\hline $\mathrm{C}(08)$ & $3328(4)$ & $9217(3)$ & $274(11)$ & $38(1)$ \\
\hline $\mathrm{O}(03)$ & $3482(3)$ & $8072(2)$ & $1863(9)$ & $54(1)$ \\
\hline $\mathrm{C}(09)$ & $3918(4)$ & $8755(4)$ & $2892(12)$ & $44(2)$ \\
\hline $\mathrm{C}(10)$ & $3629(5)$ & $8657(4)$ & $5049(14)$ & $57(2)$ \\
\hline $\mathrm{C}(11)$ & $2838(4)$ & $8033(6)$ & $4873(15)$ & $70(3)$ \\
\hline $\mathrm{O}(04)$ & $2571(4)$ & $7663(5)$ & $6821(12)$ & $98(3)$ \\
\hline $\mathrm{C}(12)$ & $2920(6)$ & $7529(5)$ & $3282(14)$ & $77(3)$ \\
\hline $\mathrm{C}(13)$ & $2128(6)$ & $7107(6)$ & $2186(19)$ & $80(3)$ \\
\hline $\mathrm{O}(05)$ & $2196(3)$ & $6777(4)$ & $362(10)$ & $80(2)$ \\
\hline
\end{tabular}

${ }^{\mathrm{a}}\left(\mathrm{U}_{\mathrm{eq}}=1 / 3 \mathrm{~S}_{\mathrm{i}} \mathrm{S}_{\mathrm{j}} \mathrm{u}_{\mathrm{ij}} \mathrm{a}{ }{ }_{\mathrm{i}} a{ }_{\mathrm{j}} a_{\mathrm{i}} a_{\mathrm{j}}\right)$

\section{Results}

\subsection{X-ray diffraction}

The final atomic coordinates and temperature factors of non-hydrogen atoms are available from the Journal Data Bank and given in Table 2, Table 3 and Table 4. The atom numbering and the bond lengths are reported in Fig. 2 $(\mathrm{a}, \mathrm{b}, \mathrm{c})$, the valence angle in Fig. $3(\mathrm{a}, \mathrm{b}, \mathrm{c})$.

Compounds II and IV possess two molecules in the asymmetric unit whereas only one is present in the asymmetric unit of compound V. In each compound, crystal packing is assured by hydrogen bonds. Their geometrical characteristics are summarized in Table 5. The ordering in the crystal network of compounds II and IV is characterized by a parallel arrangement of the planar moieties of the molecules. The short distance between the two considered partners (3.5-4.0 $\AA$ ) allows a $\pi-\pi$ interaction which could lead to a charge transfer.

Compound IV co-crystallizes with two water molecules. The first co-crystallization molecule is involved in hydrogen bonds with the bromine atom $\left(\mathrm{O}_{\mathrm{w1}}-\mathrm{Br}_{21}\right.$ distance $=3.105 \AA$ ) and with the oxygen atom of the second water molecule $\left(\mathrm{O}_{\mathrm{w} 1}-\mathrm{O}_{\mathrm{w} 2}: 2.620 \AA\right)$. This latter equally interacts with the $\mathrm{O}_{5}$ of the ribose moiety $\left(\mathrm{O}_{5}-\mathrm{O}_{\mathrm{w} 2}: 2.817\right.$ $\AA$ ). The parallel ordering is not observed in the crystal network of the compound $\mathrm{V}$ on account of its space group $\left(\mathrm{P} 6_{1}\right) \cdot$

The two molecules constituting the asymmetric unit of furan-2-yl (II) and bromofuran-2-yl (IV) gather in dimers by formation of $\mathrm{H}$ bonds between the two uracil rings. $\mathrm{N},-\mathrm{O}_{2} 2$ and $\mathrm{N}_{21}-\mathrm{O}_{2}$ distances are, respectively, 2.752(5) $\AA$, 2.982(5) Á for compound II. Distance between $\mathrm{N}_{1}-\mathrm{O}_{2}$ and $\mathrm{N}_{21}-\mathrm{O}_{22}$ for compound IV are 2.836(6) $\mathrm{A}$ and 2.839(6) $\AA$ ' (Table 5). On the contrary, compound V describes no hydrogen dimeric bonds.

X-ray crystal structures of two similar analogues 5-(5-thien-2-yl)-2'-deoxyuridine (I) and 5-(5-bromothien-2-yl)2'-deoxyuridine (III), have been previously reported (Creuven et al., 1995). 


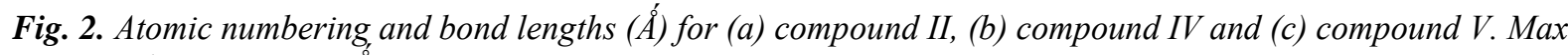

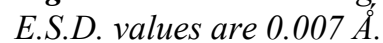
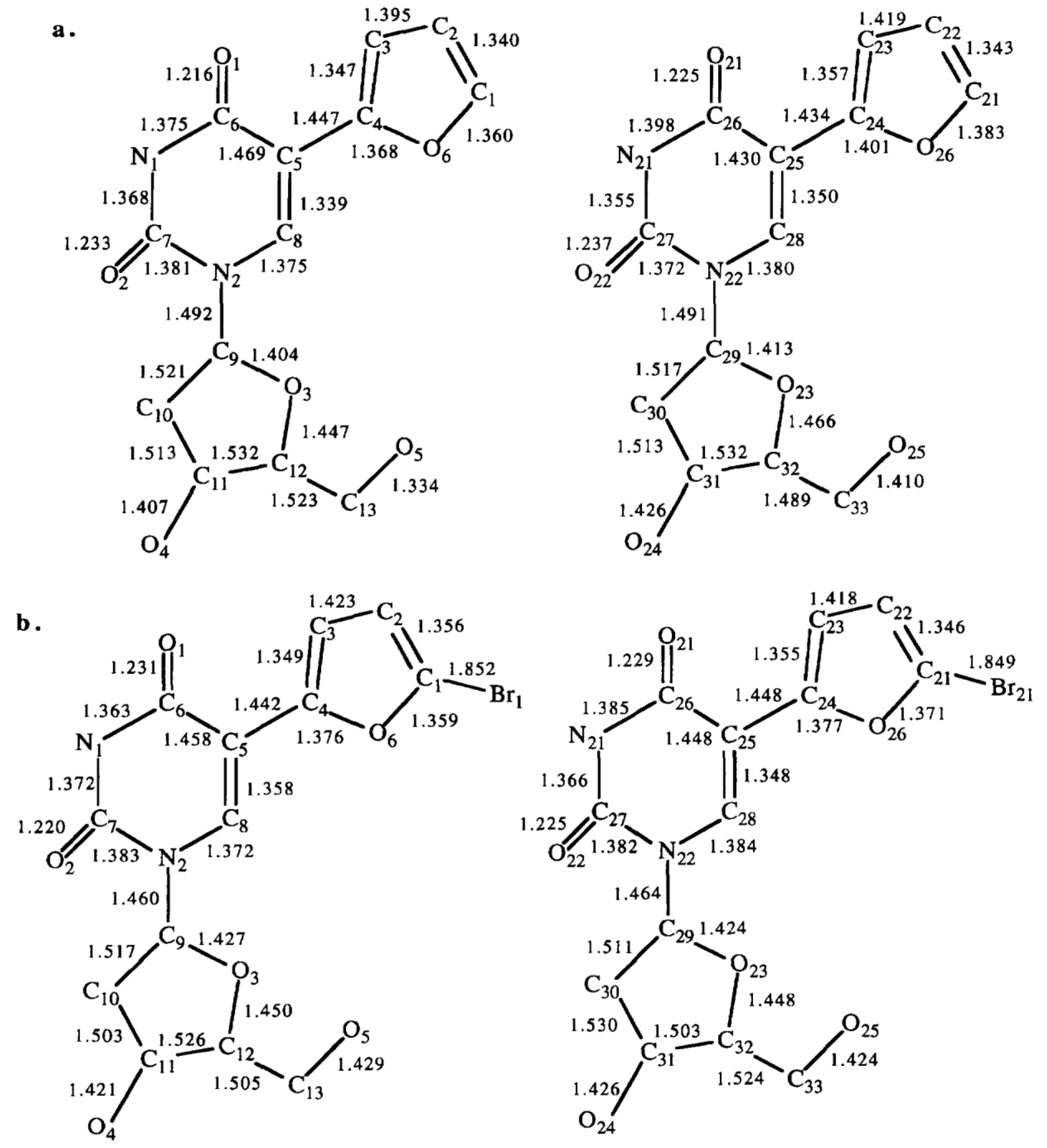
The observed bond lengths and angles in the three compounds correspond to standard values, except for the $\mathrm{C}_{4^{-}}$ $\mathrm{C}_{5}$ bond which is significantly longer (1.434-1.448 $\AA$ ) than a standard $\mathrm{C}_{\mathrm{sp}}^{2}-\mathrm{C}_{\mathrm{sp}}^{2}$ bond (1.394 $\AA$ ). The torsion angles $\left(\mathrm{C}_{7}-\mathrm{N}_{2}-\mathrm{C}_{9}-\mathrm{C}_{10}\right)$ vary from one molecule to another (Table 6). The orientation of the sugar moiety versus the uracil ring is variable. The torsion angles $\mathrm{C}_{3}-\mathrm{C}_{4}-\mathrm{C}_{5}-\mathrm{C}_{8}\left(\mathrm{C}_{23}-\mathrm{C}_{24}-\mathrm{C}_{25}-\mathrm{C}_{28}\right)$ listed in Table 6 reveal a quasicoplanar orientation of the uracil group and the five-membered ring with an angle value of about $36^{\circ}$.

For thienyl analogues (I, III, V), the sulphur atom is located in the vicinity of the carbonyl group of the uracil ring. The $S_{1}$ and $O_{1}$ atoms participate in an intramolecular interaction (Lozac'h, 1971), leading to the formation of 'pseudo-5-membered ring'. The S-O distance (Table 7) is shorter than the van der Waals contacts (3.25 ̊́). For furanyl analogues (II, IV), the substituent in the 5-position is oriented in such a way that the oxygen atoms of the uracil moietyand of the furanyl ring are pointed away from each other. Energy calculations (Olivier et al., 1994) confirm the favourable crystallographic conformation (about $4.0 \mathrm{kcal} / \mathrm{mol}$ ) with the sulphur atom (I, III, V) located in the neighbourhood of the carbonyl function and the furanyl oxygen atom (II, IV) located at the opposite side.

Fig. 2 (c).

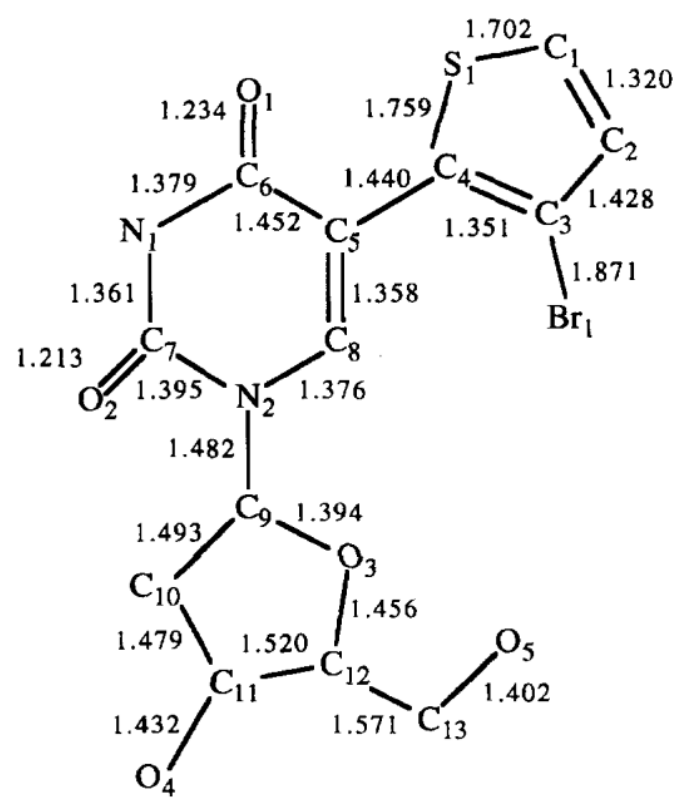

\section{Discussion}

Crystal data of the five deoxyuridine analogues reported here have been compared in order to explain their different affinities for the HSV-1 thymidine kinase.

All molecules have a planar bicyclic conformation. The sulphur atom of the thienyl compounds (I, III, V) is positioned in the neighbourhood of the carbonyl group of the uracil moiety. Thus, the sulphur atoms participate in an intramolecular contact (S-O interaction) leading to the formation of a 'pseudo-ring'. In contrast, in compounds II and IV, the oxygen atom of the carbonyl function interacts with a C-H of the furanyl ring.

It is clear that the orientation of the heterocyclic moiety in the 5-position depends on the nature of the heteroatom (sulphur or oxygen atom). The oxygen of the furanyl ring is pointed in the opposite direction to the sulphur of the thienyl ring. However, the difference in orientation could not be the only factor to explain the difference in TK affinity of the modified nucleosides as compounds I (thienyl), II (furanyl) and III (5-bromothienyl) show a high affinity for the enzyme and IV (bromofuranyl) and V (3-bromothienyl) demonstrate a low affinity for the same enzyme. An interesting observation is the fact that, when introducing a bromine sub-stituent in the five position of I, a compound (III) is obtained with similar TK affinity. The introduction of a bromine in the five 
position of II gives a compound (IV) with a lower affinity for the enzyme. As the orientation of the heterocyclic moiety does not change, the position of the bromine atom might be crucial.

In compound III, the S-O intramolecular interaction tends to bring the bromine atom in the upper parts of the molecule. Other substituents (chlorine or methyl group) placed in that same position also lead to active compounds with the same structural properties: the 5-(5-chlorothien-2-yl)-2'-dUrd (Olivier et al., 1994) and the 5-(5-methylthien-2-yl)-2'-dUrd (Creuven et al., 1995). If, however, the bromine atom is shifted from $\mathrm{C}_{1}$ to $\mathrm{C}_{3}$ of the thienyl ring $(\mathrm{V})$, the affinity for HSV-1 TK decreases $(61.4 \mu \mathrm{M})$ and the affinity is comparable with the affinity of the bromofuranyl congener (IV).

It thus seems clear that the affinity for the HSV-1 TK can be explained by two structural factors. The nature of the heteroatom in the five-membered ring determines the orientation of this ring with respect to the uracil moiety. The substituent on the five-membered ring (a bromine atom) creates a steric effect unfavourable for high affinity when placed in the lower part of the molecule (in the neighbourhood of the $\mathrm{H}_{6}$ of the uracil ring). Indeed, a bromine atom linked to $C_{1}$ of the furanyl (IV) or to $C_{3}$ of the thienyl (V) decreases the affinity while the affinity is retained when the bromine is placed in the $\mathrm{C}_{1}$ position of the thienyl ring (III). The superposition of the three bromine substituted compounds is shown in Fig. 4 (compounds III, IV and V are, respectively, represented in dotted, dashed and solid lines) in order to demonstrate the unfavourable zone. This analysis allows us to display structural requirements necessary for high affinity against HSV-1 thymidine kinase and might therefore contribute to the synthesis of new potent antiviral agents. 
Fig. 3. Valence angle $\left({ }^{\circ}\right)$ for (a) compound II, (b) compound IV and (c) compound V. Max E.S.D. values are $0.4^{\circ}$.
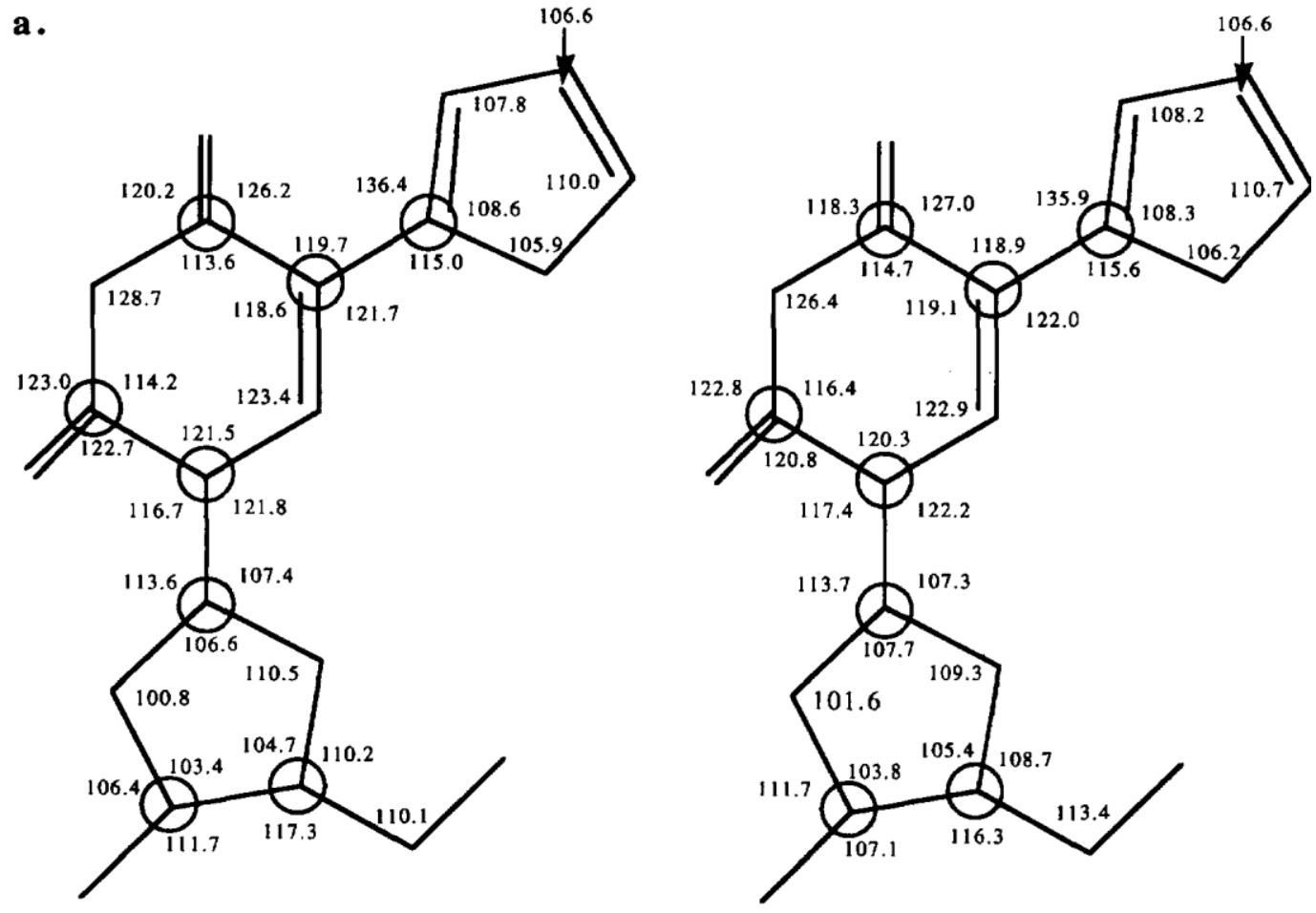

b.
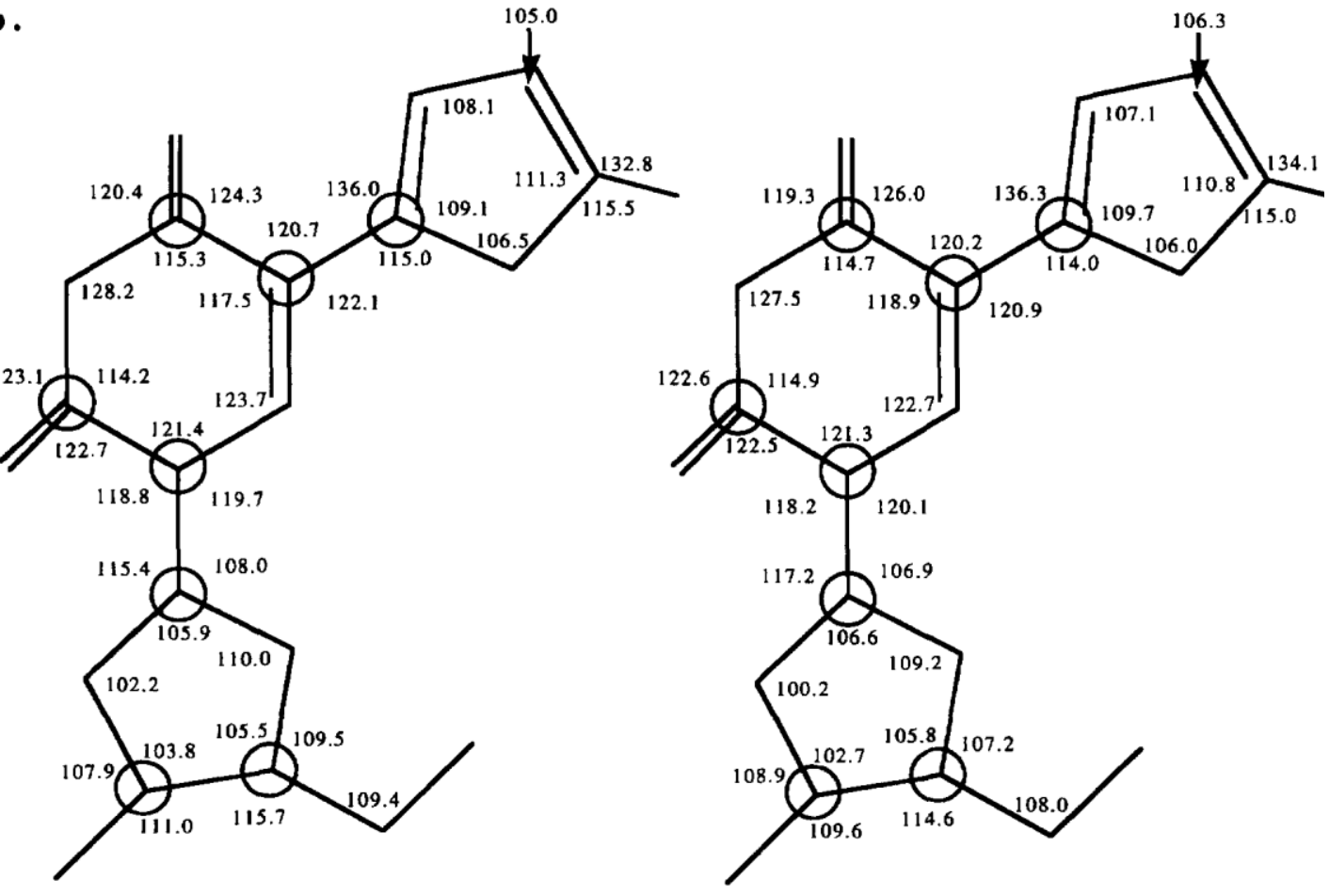
Published in Antiviral Research (1996), vol. 30; 63-74

Status : Postprint (Author's version)

Fig. 3(c).

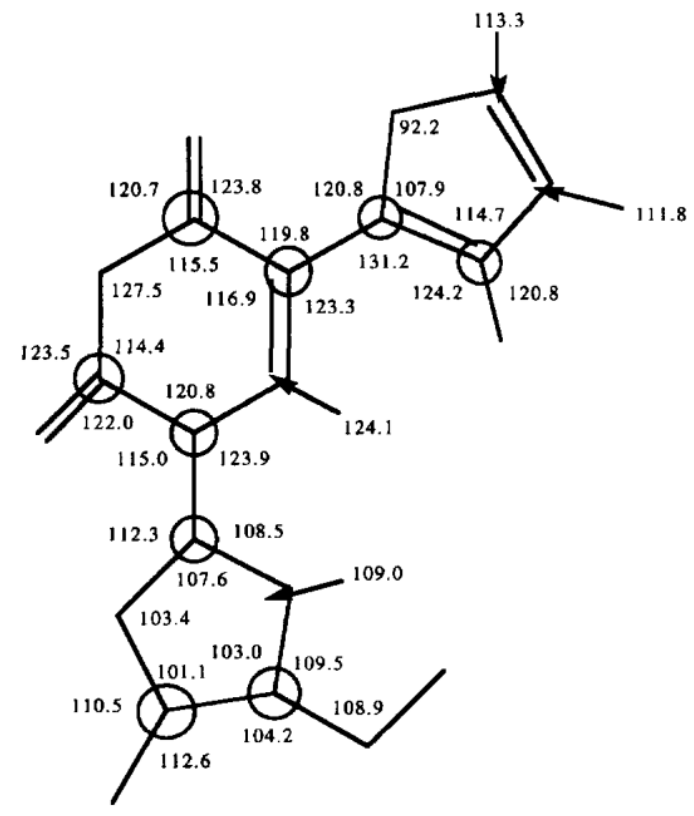


Table 5 Hydrogen bonds for compounds II, IV and V

\begin{tabular}{|c|c|c|c|c|}
\hline \multirow{2}{*}{\multicolumn{5}{|c|}{ Compound II }} \\
\hline & & & & \\
\hline \multicolumn{5}{|l|}{$\mathrm{N}-\mathrm{H}-\mathrm{O}$} \\
\hline $\mathrm{N}(1)_{i}-\mathrm{H}(\mathrm{N} 1)_{\mathrm{i}}-\mathrm{O}(22)^{\mathrm{a}}{ }_{i i}$ & 0.864 & $2.752(5)$ & 1.899 & 169.2 \\
\hline $\mathrm{N}(21)_{\mathrm{i}}-\mathrm{H}(\mathrm{N} 21)_{\mathrm{i}} \cdot-\mathrm{O}(2)^{\mathrm{a}}{ }_{v i}$ & 0.982 & $2.982(5)$ & 2.015 & 167.8 \\
\hline $\mathrm{O}-\mathrm{H}-\mathrm{O}$ & $\mathrm{O}-\mathrm{H}(\AA)$ & $\mathrm{O}-\mathrm{O}(\AA)$ & $\mathrm{H}-\mathrm{O}(\AA)$ & $\mathrm{O}-\mathrm{H}-\mathrm{O}\left(^{\circ}\right)$ \\
\hline $\mathrm{O}(4)_{i}-\mathrm{H}(\mathrm{O} 4)_{i}-\mathrm{O}(\mathrm{l})_{f f f}$ & 0.902 & $2.952(5)$ & 2.125 & 152.0 \\
\hline $\mathrm{O}(5)_{i}-\mathrm{H}(\mathrm{O} 5)_{i}-\mathrm{O}(23)_{i v}$ & 1.199 & $3.091(7)$ & 2.501 & 108.1 \\
\hline $\mathrm{O}(24),-\mathrm{H}(\mathrm{O} 24)-\mathrm{O}(2)_{v}$ & 0.859 & $2.859(5)$ & 2.002 & 175.3 \\
\hline$i=x, y, z$ & \multicolumn{2}{|l|}{$i i i=1+x, y, 2$} & \multicolumn{2}{|l|}{$v=-1+x, y,-\backslash+z$} \\
\hline$i i=x, y, z+1$ & \multicolumn{2}{|l|}{$i v=1-x, y-1 / 2,-z$} & \multicolumn{2}{|l|}{$v i=x, y,-1+x$} \\
\hline \multicolumn{5}{|l|}{ Compound IV } \\
\hline $\mathrm{N}-\mathrm{H}-\mathrm{O}$ & N-H (Á) & $\mathrm{N}-\mathrm{O}(\dot{\AA})$ & $\mathrm{H}-\mathrm{O}(\AA)$ & $\mathrm{N}-\mathrm{H}-\mathrm{O}\left({ }^{\circ}\right)$ \\
\hline $\mathrm{N}(1)_{i}-\mathrm{H}(\mathrm{N} 1)_{i}-\mathrm{O}(2)^{\mathrm{a}}{ }_{i i}$ & 0.621 & $2.836(6)$ & 2.217 & 174.5 \\
\hline $\mathrm{N}(21)_{i}-\mathrm{H}(\mathrm{N} 21)_{i}-\mathrm{O}(22)^{\mathrm{a}}{ }_{i i i}$ & 0.771 & $2.839(6)$ & 2.096 & 162.0 \\
\hline $\mathrm{O}-\mathrm{H}-\mathrm{O}$ & $\mathrm{O}-\mathrm{H}(\AA)$ & $\mathrm{O}-\mathrm{O}(\AA)$ & $\mathrm{H}-\mathrm{O}(\AA)$ & $\mathrm{O}-\mathrm{H}-\mathrm{O}\left(^{\circ}\right)$ \\
\hline $\mathrm{O}(4)_{i}-\mathrm{H}(\mathrm{O} 4)_{i}-\mathrm{O}(21)_{i v}$ & 0.847 & $2.799(7)$ & 2.032 & 150.0 \\
\hline $\mathrm{O}(5)_{i}-\mathrm{H}(\mathrm{O} 5)_{i}-\mathrm{O}(24)_{v}$ & 0.964 & $2.691(7)$ & 1.749 & 164.6 \\
\hline $\mathrm{O}(24)_{i}-\mathrm{H}(\mathrm{O} 24)_{i}-\mathrm{O}(\mathrm{l})_{i i}$ & 0.812 & $2.695(6)$ & 2.080 & 132.3 \\
\hline $\mathrm{O}(5)_{i}-\mathrm{H}(\mathrm{O} 5)_{i}-O(3)_{v i}$ & 1.047 & $2.788(7)$ & 1.783 & 159.2 \\
\hline $\mathrm{O}(\mathrm{W} 1)_{i}-\mathrm{H}(\mathrm{OW} 1)_{i}-\mathrm{O}(\mathrm{W} 2)_{i}$ & 1.038 & $2.620(14)$ & 1.591 & 170.0 \\
\hline $\mathrm{O}(5)_{i}-\mathrm{H}(\mathrm{O} 5)_{i}-\mathrm{O}(\mathrm{W} 2)_{i}$ & & & 2.817 & \\
\hline $\mathrm{i}=x, y, z$ & \multirow{2}{*}{\multicolumn{2}{|c|}{$\begin{array}{l}H i=-x, y,-1-\mathrm{z} \\
i v=1 / 2-x, 1 / 2+\mathrm{y},-1-\mathrm{z}\end{array}$}} & \multirow{2}{*}{\multicolumn{2}{|c|}{$\begin{array}{l}v=-1 / 2+\mathrm{x}, 1 / 2+\mathrm{y}, \mathrm{z} \\
v i=x,-1+y, \mathrm{z}\end{array}$}} \\
\hline$i i=-x, y,-z$ & & & & \\
\hline \multicolumn{5}{|l|}{ Compound V } \\
\hline $\mathrm{O}-\mathrm{H}-\mathrm{O}$ & O-H (Á) & $\mathrm{O}-\mathrm{O}(\dot{A})$ & $\mathrm{H}-\mathrm{O}(\AA)$ & $\mathrm{O}-\mathrm{H}-\mathrm{O}\left(^{\circ}\right)$ \\
\hline $\mathrm{O}(4)_{i}-\mathrm{H}(\mathrm{O} 4)_{i}-\mathrm{O}(1)_{i i}$ & 0.929 & $2.687(13)$ & 2.328 & 102.5 \\
\hline$i=x, y, z$ & $i i=y,-x+y, 5 / 6+z$ & & & \\
\hline
\end{tabular}

${ }^{\mathrm{a}}$ Hydrogen bonds implicated in dimers. 
Table 6: Torsion angle between (a) the five-membered ring and uracil moiety, (b) the uracil and the sugar moieties for compounds $I-V$

\begin{tabular}{|l|l|l|l|l|l|}
\hline Angles $\mathrm{O}$ & I & II & III & IV & V \\
\hline (a) $\mathrm{C}_{3}-\mathrm{C}_{4}-\mathrm{C}_{5}-\mathrm{C}_{8}$ & $-2.7(10)$ & $-178.5(7)$ & $7.0(3)$ & $-175.3(6)$ & $36.2(14)$ \\
\hline (a) $\mathrm{C}_{23}-\mathrm{C}_{24}-\mathrm{C}_{25}-\mathrm{C}_{28}$ & $2.6(9)$ & $-177.0(6)$ & $-5.0(3)$ & $173.9(6)$ & \\
\hline (b) $\mathrm{C}_{7}-\mathrm{N}_{2}-\mathrm{C}_{2}-\mathrm{C}_{10}$ & $90.6(7)$ & $76.2(6)$ & $125.9(15)$ & $124.9(5)$ & $80.2(9)$ \\
\hline (b) $\mathrm{C}_{27}-\mathrm{N}_{22}-\mathrm{C}_{29}-\mathrm{C}_{30}$ & $121.9(6)$ & $93.2(5)$ & $81.6(17)$ & $138.6(4)$ & \\
\hline
\end{tabular}

Table 7: S-O distances (Á) for compounds I, III, V

\begin{tabular}{|l|l|l|}
\hline Compound & $\mathrm{S}_{1}-\mathrm{O}_{1}$ & $\mathrm{~S}_{21}-\mathrm{O}_{21}$ \\
\hline $\mathrm{I}$ & $2.819(5)$ & $2.845(5)$ \\
\hline III & $2.834(13)$ & $2.806(15)$ \\
\hline V & $2.870(8)$ & - \\
\hline
\end{tabular}

Fig. 4. View of the superposition of the three bromine substituted compounds (III, IV and V, respectively, represented by dotted, dashed and solid lines). The bromine positions that are unfavourable to the interaction of the compounds with the HSV-1 TK are indicated.

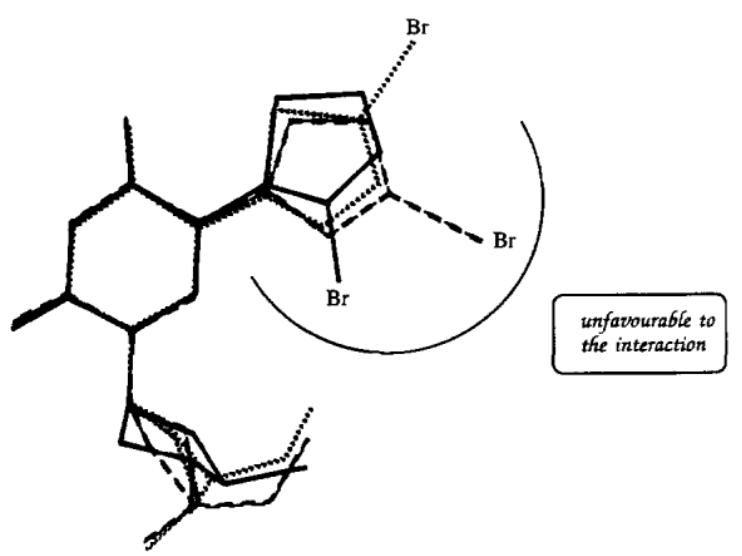

\section{Acknowledgements}

The authors would like to thank the National Belgian Foundation for Scientific Research (FNRS) and the NFWO, IBM-Belgium and the Facultés Universitaires Notre-Dame de la Paix for the use of the scientific computing facility. Thanks to B. Norberg for helpful collaboration.

\section{References}

Bohman, C., Balzarini, J., Wigerinck, P., Van Aerschot, A., Herdewijn, P. and De Clercq, E. (1994) Mechanistic of cytostatic action of novel 5-(thien-2-yl)- and 5-(furan-2-yl) substituted pyrimidine nucleoside analogues against tumor cells transfected by the thymidine kinase gene of herpes simplex virus. J. Biol. Chem. 269, 8036-8043.

Creuven, I., Evrard, C., Olivier, A., Evrard, G., Wigerinck, P., Herdewijn, P. and Durant, F. (1995) 5-(Thien-2-yl) uracil analogues: 5-(5methylthien-2-yl)-2'-deoxyuridine, 5-(5-thien-2-yl)-2'-deoxyuridine and 5-(5-bromothien-2-yl)-2'-de-oxyuridine. J. Chem. Crystallogr. submitted.

De Clercq, E. (1981) Nucleoside analogs as antiviral agents. Acta Microbiol. Acad. Sci. Hung. 28, 289-306.

De Clercq, E. and Torrence, P.F. (1978) Nucleoside analogs with antiviral activity. J. Carbohydr. Nucleosides Nucleotides 5, $187-224$. 
De Clercq, E., Descamps, J., De Somer, P., Barr, P.J., Jones, A. and Walker, R.T. (1979) Pharmacokinetics of (E)-5-(2-bromovinyl)-2'deoxyuridine in mice. Proc. Natl. Acad. Sci. USA 76, 2947-2950.

De Clercq, E., Desgranges, C., Herdewijn, P., Sim, I.S., Jones, A.S., McLean, M.J. and Walker, R.T. (1986) Synthesis and antiviral activity of (E)-5-(2-bromovinyl)uracil and (E)-5-(2-bromovinyl)uridine. J. Med. Chem. 29, 213-217.

Derse, D.D., Cheng, Y.-C., Furman, P.A., St. Clair, M.H. and Elion, G.B. (1981) Inhibition of purified human and herpes-simplex virusinduced DNA-polymerase by 9-(2-hydrox-yethoxymethyI)guanine triphosphate effects on primer-template function. J. Biol. Chem. 256, $1447-1451$

Desgranges, C., Razaka, G., Rabaud, M., Bricaud, H., Balzarini, J. and De Clercq, E. (1983) Phosphorolysis of (is)-5-(2-bromovinyl)-2'deoxyuridine (BVDU) and other 5-substituted-2'-deoxyuridine by purified human thymidine phosphorylase and intact blood platelets. Biochem. Pharmacol. 32, 3583-3590.

Elion, B.G., Furman, P.A., Fyfe, F.A., De Mirande, P., Beauchamps, L. and Schaffer, H.J. (1977) Selectivity of action of an antiherpetic agent, 9-(2-hydroxyethoxy-methyl)guanine. Proc. Natl. Acad. Sci. USA 74, 5716-5720.

Johnson, C.K. (1976) ORTEP Report ORNL-5138. Oak Ridge National Laboratory, Oak Ridge, Tennesse, USA.

Luyten, I., Jie, L., Van Aerschot, A., Pannecouque, C, Wigerinck, P., Rozenski, J., Hendrix, C, Wang, C, Wiebe, L., Balzarini, J., De Clercq, E. and Herdewijn, P. (1995) 2'-Deoxyuridine with 5-heteroaromatic substituent: synthesis and biological evolution. Antiviral Chem. Chemother. 6, 262-270.

Lozac'h, N. (1971) Adv. Heterocycl. Chem. 13, 161-234.

Olivier, A., Creuven, I., Evrard, C, Evrard, G., Dory, M., Van Aerschot, A., Wigerinck, P., Herdewijn, P. and Durant, F. (1994) Stereoelectronic properties of five anti-HSV-1 2'-de-oxynucleosides analogues with heterocyclic substituents in the 5-position: a comparison with BVDU. Antiviral Res. 24, 289-304.

Ruth, J.L. and Cheng, Y.-C. (1981) Nucleoside analogs with clinical potential in antivirus chemotherapy. The effect of several thymidine and 2'-deoxycytidine analog 5'-triphos-phates on purified human (alpha, beta) and herpes-simplex virus (type-1, type-2) DNA-polymerase. Mol. Pharmacol. 20, 415-422.

Sheldrick, G.M. (1986) SHELXS86. Program for the solution of crystal structures. Institut fur Anorganische Chemie der Universität, Göttingen, Germany.

Sheldrick, G.M. (1993) SHELXL93. Program for crystal structure determination. Institut fuer Anorg. Chemie, Univ. of Göttingen, Germany.

Spek, A. L. (1990) PLATON92. Acta Cryst. A 46, C3.

Wigerinck, P., Pannecouque, C, Snoeck, T., Claes, P., De Clercq, E. and Herdewijn, P. (1991a) 5-(5-Bromothien-2-yl)-2'-deoxyuridine and 5-(5-chlorothien-2-yl)-2'-deoxyuridine are equipotent to (E)-5-(2-bromovinyl)-2'-deoxyuridine in the inhibition of herpes simplex virus type1 replication. J. Med. Chem. 34, 2383-2389.

Wigerinck, P., Snoeck, R., Claes, P., De Clercq, E. and Herdewijn, P. (1991b) Synthesis and antiviral activity of 5-heteroaryl substituted 2'deoxyuridine. J. Med. Chem. 34, 1767-1772.

Wigerinck, P., Kerremans, L., Claes, P., Snoeck, R., Maudgal, P., De Clercq, E. and Herdewijn, P. (1993) Synthesis and antiviral activity of 5-thien-2-yl-2'-deoxyuridine analogues. J. Med. Chem. 31, 538-543. 